\title{
Temperature changes during strenuous exercise in different body compartments of the horse
}

\author{
M. A. Weishaupt ${ }^{1}$, H. Staempfli2, R. Billeter ${ }^{3}$ and R. Straub 4 \\ ${ }^{1}$ Department of Veterinary Surgery, University of Zurich, Switzerland \\ ${ }^{2}$ Veterinary Teaching Hospital, Ontario Veterinary College, University of Guelph, Canada \\ 3Institute of Anatomy, University of Berne, Switzerland \\ ${ }^{4}$ Clinic of Equine Medicine, University of Berne, Switzerland
}

\begin{abstract}
Summary
In order to evaluate metabolic heat generation and heat dissipation of strenuously exercising horses, thermal response in various body compartments was simultaneously and continuously monitored. Two horses were subjected to a long-term incremental exercise protocol with progressive increase of treadmill speed, slope and draught load. The temperatures were determined in the following structures and cavities using implanted thermocouple probes: middle gluteal, semitendinosus and masseter muscles, right cardiac ventricle, jugular vein, abdomen, rectum and subcutaneous tissue. The kinetics of temperature increases were similar for locomotor muscles, right ventricle (body core), abdomen and subcutaneous tissue. At peak exercise the highest temperatures were measured in locomotor muscle $\left(43.3^{\circ} \mathrm{C}\right)$. The blood temperature in the jugular vein was $\approx 1^{\circ} \mathrm{C}$ below body core temperature at rest and $\approx 3^{\circ} \mathrm{C}$ below at peak exercise. During and after exercise the rectal temperature never accurately assessed core and compartment temperatures. Maximal rectal temperatures peaked $\approx 1^{\circ} \mathrm{C}$ below body core temperature with a lag time of $10-15$ minutes.
\end{abstract}

Keywords: Thermoregulation; exercise hyperthermia; heat transfer; muscle temperature; blood temperature; rectal temperature

\begin{abstract}
Temperaturveränderungen in verschiedenen Körperkompartimenten des Pferdes während intensiver Belastung
Um die metabolische Wärmeproduktion und -abgabe von intensiv belasteten Pferden zu messen, wurde die thermale Reaktion in verschiedenen Körperkompartimenten gleichzeitig und kontinuierlich aufgezeichnet. Zwei Pferde absolvierten auf dem Laufband eine Langzeitbelastung mit einem progressiven Anstieg von Laufgeschwindigkeit, Steigung des Laufbandes und Zuglast. Mittles implantierter Thermosonden wurde die Temperatur in den folgenden Strukturen und Körperhöhlen gemessen: mittlerer M. glutaeus, M. semitendinosus, M. masseter, rechte Herzkammer, vena jugularis, Abdomen, Rektum und subkutanes Gewebe. Die Kinetik des Temperaturantieges war für die Bewegungsmuskulatur, rechte Herzkammer (Körperkern), Abdomen und subkutanes Gewebe ähnlich. Zu Zeiten der Spitzenbelastung wurde die höchste Temperatur in der Bewegungsmuskulatur gemessen $\left(43,3^{\circ} \mathrm{C}\right)$. Im Ruhezustand lag die Temperatur des Blutes, in der vena jugularis gemessen, $\sim 1^{\circ} \mathrm{C}$ unterhalb der Körperkerntemperatur, zu Zeiten der Spitzenbelastung $\sim 3^{\circ} \mathrm{C}$ unterhalb. Während und nach Belastung konnte die rektal gemessene Temperatur niemals genau Aufschluß über die Temperatur im Kern und den Kompartimenten geben. Die höchste rektal gemessene Temperatur lag $\sim 1^{\circ} \mathrm{C}$ unterhalb der Körperkerntemperatur. Diese Maximum wurde 10-15 min nach dem der Kerntemperatur erreicht.
\end{abstract}

Schlüsselwörter: Thermoregulation, Überhitzung bei Belastung, Wärmeaustausch, Muskeltemperatur, Bluttemperatur, Rektaltemperatur

\section{Introduction}

The inefficient metabolic conversion of chemical energy into mechanical power leads, at the muscular level, to build up of a significant amount of metabolic heat during intensive physical effort in the horse. It is estimated that only $20 \%$ of the total stored energy is available for contractile activity (Astrand and Rodahl, 1986). Under adverse ambient conditions, such as high temperature and humidity, the thermoregulatory system of the horse and coupled mechanisms for heat dissipation are dramatically challenged, especially when associated with high intensity exercise. Performance limitation and life-threatening problems are potential sequelae to heat accumulation. Careful monitoring during equine endurance and three day event competitions is essential to prevent hyperthermia and ensure animal welfare.

Very little is known on heat accumulation and distribution in different tissue compartments of the equine athlete. This study was therefore initiated to understand some of the patterns of heat flow and heat dissipation from its site of generation - the locomotor muscles, to the different compartments of the body. The thermal response over time to endurance exercise was recorded continuously and simultaneously in several body compartments of horses exercising on a treadmill.

\section{Materials and methods}

Two Swiss Warmblood geldings (10 and 12 year old; body weights 558 and $573 \mathrm{~kg}$ ) were used in this study. They were adapted to the treadmill (Mustang 2200, Kagra AG, Fahrwangen, Switzerland), to the harness and the traction force installation and were conditioned over a six week period with a daily 45 minute treadmill exercise program at submaximal work intensities. This exercise protocol included work loads with varying speeds, inclines and draught loads. One week prior to the experiments the horses were capable to complete the experimental exercise protocol. This exercise protocol (Tab. 1) consisted of a 30 minute in- 
Tab. 1: Incremental exercise protocol.

\begin{tabular}{|l|c|c|c|l|}
\hline & $\begin{array}{l}\text { Time interval } \\
{[\text { minute }]}\end{array}$ & $\begin{array}{l}\text { Treadmill } \\
\text { speed }\left[\mathrm{m}^{-1}{ }^{-1}\right]\end{array}$ & $\begin{array}{l}\text { Treadmill } \\
\text { incline }[\%]\end{array}$ & $\begin{array}{l}\text { Draught work } \\
{[\mathrm{kg}(\mathrm{N})]}\end{array}$ \\
\hline Rest & 5 & 0 & 0 & 0 \\
\hline Warm up & 5 & 1.6 & 0 & $10(98)$ \\
\hline & 5 & 1.6 & 6 & $10(98)$ \\
\hline & 5 & 1.6 & 9 & $10(98)$ \\
\hline Exercise & 5 & 3.0 & 3 & $10(98)$ \\
\hline & 5 & 3.0 & 3 & $20(196)$ \\
\hline & 5 & 3.5 & 3 & $30(294)$ \\
\hline & 5 & 3.5 & 6 & $30(294)$ \\
\hline & 2 & 4.0 & 6 & $30(294)$ \\
\hline & 2 & 4.0 & 6 & $40(392)$ \\
\hline & 2 & 4.0 & 6 & $50(490)$ \\
\hline & 2 & 4.5 & 6 & $50(490)$ \\
\hline & 2 & 4.5 & 6 & $60(588)$ \\
\hline
\end{tabular}

cremental exercise test, during which the speed was increased from 3.0 to $4.5 \mathrm{~m} \cdot \mathrm{s}^{-1}$, the treadmill slope from 0 to $6 \%$ and the added draught load from 98 to $589 \mathrm{~N}$. Horses were trotting during the whole exercise test and were subsequently standing during the recovery phase quietly on the treadmill with the fan turned off. The tests were conducted in a non-air-conditioned laboratory in April (max. room temperature $16^{\circ} \mathrm{C}$; max. air humidity $75 \%$ ). The airflow velocity directed against the anterior and dorsal aspects of the exercising animal was adjusted according to treadmill speed. Once fully instrumented with the implanted temperature probes the horses were subjected to a single exercise test.
Local temperature changes over time were measured at the following specific anatomical sites: M. gluteus medius at a depth of 80 $\mathrm{mm}, \mathrm{M}$. semitendinosus at a depth $60 \mathrm{~mm}$, M. masseter at a depth of $20 \mathrm{~mm}$, right jugular vein, right cardiac ventricle, rectum, abdominal cavity and in subcutaneous tissue lateral at the neck.

Tissue and jugular vein blood temperatures were measured continuously using gas sterilised Nickel-Chromium (Nickel thermocouple wires Type K), $1.2 \mathrm{~mm}$ in diameter (Suprag AG, Zurich, Switzerland), implanted immediately before exercise through a $13 \mathrm{G}$ teflon catheter placed under aseptic conditions and local anaesthesia with a blunt stilet. Catheters were held in position with sutures. Before sterilisation, thermocouples were threaded through Luer fittings, which sealed the catheters and ensured the accurate positioning of the thermocouple tip. For the purpose of measuring right ventricle blood temperature and pressure a $1.10 \mathrm{~m}$ long and $2 \mathrm{~mm}$ wide thermoplastic cardiac catheter with an integrated Nickel-Chromium (Nickel thermocouple wire $(\varnothing 0.5 \mathrm{~mm})$ was used. The accurate positioning of the right cardiac ventricle probe was verified by pressure curve recordings. During the entire experiment ECG recordings were performed to monitor for ventricular extra systoles. The rectal probe was mounted on a rubber balloon, which was inflated slightly once placed in the rectum to ensure direct contact to the rectal mucosa. The thermocouple tip was placed approximately $25-30 \mathrm{~cm}$ cranial from the anal sphincter. Abdominal temperature probes were placed through the left paralumbar fossa, over a length of $25 \mathrm{~cm}$ along the lateral abdominal wall. Temperature traces from the different sites were recorded alphanumerically every minute using a printer with integrated thermocouple amplifier and analogue-digital board (SE 490, ABB Metrawatt, GmbH, Nürnberg, Germany). Linearity calibration of each single thermocouple wire and calibration immediately after the experiment were checked in a rotating heated water bath with a calibration thermometer.

The heart rate was recorded continuously with a Hippocard heart rate monitor (Isler Bioengineering AG, Zurich, Switzerland). Venous whole blood samples for plasma lactate determination were collected in duplicates at each exercise level 15 seconds before changing to the following step.

Tab. 2: Heart rate, plasma lactate concentration, and temperature changes of the horse „Quai du Manoir" during rest, warm up, exercise and recovery.

\begin{tabular}{|c|c|c|c|c|c|c|c|}
\hline \multirow[b]{2}{*}{ Time [min] } & \multirow{2}{*}{$\frac{\text { Rest }}{0}$} & \multirow{2}{*}{\begin{tabular}{c|} 
Warm up \\
15
\end{tabular}} & \multicolumn{2}{|c|}{ Exercise } & \multicolumn{2}{|c|}{ Recovery } & \multirow{2}{*}{$\begin{array}{l}\text { Maximal values } \\
\text { (time [min]) }\end{array}$} \\
\hline & & & 35 & 45 & 55 & 105 & \\
\hline Heart rate [beats॰min $\left.{ }^{-1}\right]$ & 41 & 116 & 165 & 213 & 102 & 54 & $213(45)$ \\
\hline Lactate $\left[\left.\mathrm{mmo}|\cdot|\right|^{-1}\right]$ & 1.22 & 0.64 & 1.94 & 12.5 & 8.62 & 1.74 & $12.9(46)$ \\
\hline M. gluteus medius temperature $\left[{ }^{\circ} \mathrm{C}\right]$ & 37.6 & 38.5 & 40.8 & 43.3 & - & - & $43.3(45)$ \\
\hline M. semitendinosus temperature $\left[{ }^{\circ} \mathrm{C}\right]$ & 37.1 & 37.9 & 39.8 & 42.0 & - & - & $42.5(46)$ \\
\hline M. masseter temperature $\left[{ }^{\circ} \mathrm{C}\right]$ & 36.2 & 36.7 & 37.6 & 38.7 & 38.6 & 37.2 & $38.9(46)$ \\
\hline Right ventricle blood temperature $\left[{ }^{\circ} \mathrm{C}\right]$ & 36.3 & 37.5 & 39.2 & 41.1 & 39.0 & 37.1 & $41.1(45)$ \\
\hline Jugular vein blood temperature $\left[{ }^{\circ} \mathrm{C}\right]$ & 36.2 & 36.2 & 36.5 & 38.4 & 37.6 & 36.1 & $38.4(45)$ \\
\hline Subcutis temperature $\left[{ }^{\circ} \mathrm{C}\right]$ & 36.0 & 36.7 & 39.2 & 41.5 & 39.7 & 37.2 & $41.5(45)$ \\
\hline Abdominal temperature $\left[{ }^{\circ} \mathrm{C}\right]$ & 37.4 & 37.9 & 39.5 & 40.6 & 41.5 & 38.1 & $41.7(50)$ \\
\hline Rectal temperature $\left[{ }^{\circ} \mathrm{C}\right]$ & 37.6 & 38.0 & 38.9 & 39.9 & 40.1 & 37.7 & $40.2(57)$ \\
\hline
\end{tabular}

Thermocouple probes in locomotor muscles were removed after the end of exercise and therefore recovery values are missing. 


\section{Results}

Heart rate, plasma lactate and temperature data during rest, warm up, exercise and recovery from the horse "Quai du Manoir" are summarised in Table 2.

At $4.5 \mathrm{~m} \cdot \mathrm{s}^{-1}, 6 \%$ incline and $589 \mathrm{~N}$ draught load both horses exercised at near maximal intensities as represented by heart rates over 200 bpm (213 resp. 201 bpm). Maximal plasma lactate concentrations peaked 1 minute after completion of the exercise test at 12.9 and $12.1 \mathrm{mmolol}^{-1}$ respectively.

Initial temperatures at rest were comparable between locomotor muscles, rectum and abdominal cavity and ranged between 36.9 and $37.8^{\circ} \mathrm{C}$. Interestingly the initial temperatures of the right ventricle and jugular vein were on the average 1.0 degree lower $\left(36.3^{\circ} \mathrm{C}\right)$ compared to the other sites. The subcutaneous temperatures at rest were $36.0^{\circ} \mathrm{C}$ respectively $34.0^{\circ} \mathrm{C}$. The lowest initial temperature was measured in the masseter muscle of one horse with $31.8^{\circ} \mathrm{C}$.

At the onset of exercise, as the fan started to blow against the horse, subcutaneous temperatures showed a sharp decline of approximately 1 degree due to increased convection.

During exercise the temperature rose exponentially in all measured compartments of both horses (Fig. 1-3). The mean temperature increases during exercise time were $0.14^{\circ} \mathrm{C} \cdot \mathrm{min}^{-1}$ in locomo-

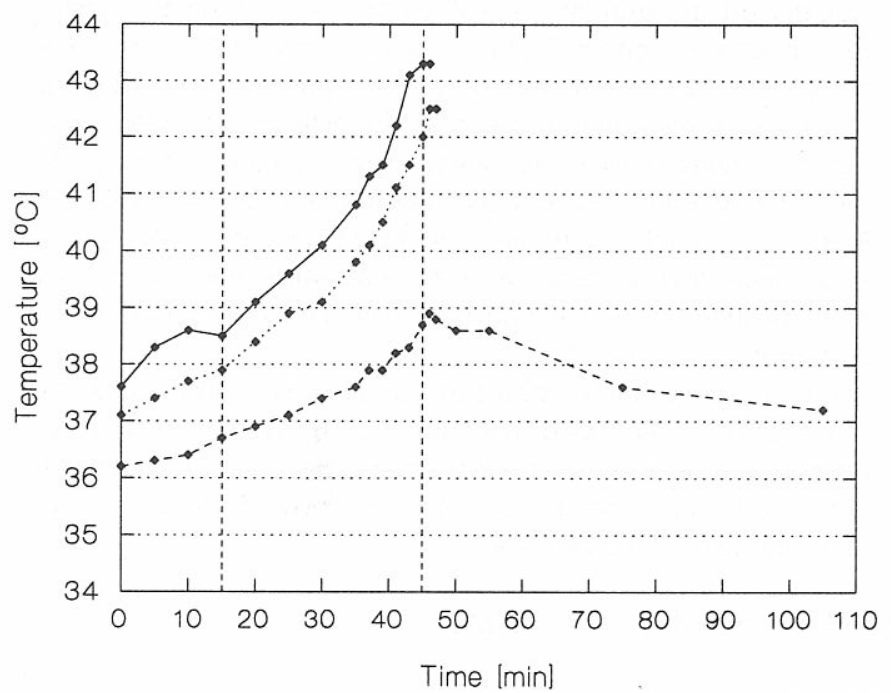

Warm Up Exercise Recovery

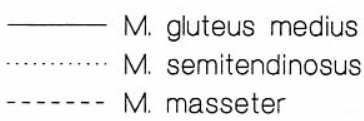

Fig. 1: Muscle temperatures of the horse „Quai du Manoir" during warm up, exercise and recovery.

tor muscles and subcutaneous tissues, $0.12^{\circ} \mathrm{C} \cdot \mathrm{min}^{-1}$ in the right ventricle and the masseter muscle, $0.10^{\circ} \mathrm{C} \cdot \mathrm{min}^{-1}$ in the abdomen, $0.09^{\circ} \mathrm{C} \cdot \mathrm{min}^{-1}$ in the jugular vein and $0.06^{\circ} \mathrm{C} \cdot \mathrm{min}^{-1}$ in the rectum.

At the end of the exercise period, the highest temperatures $\left(40.6-43.3^{\circ} \mathrm{C}\right)$ were measured in the major locomotor muscles (Fig. 1). Temperatures peaked within 1 minute after conclusion of the test and temperature differences to resting values were on average $5.5^{\circ} \mathrm{C}$. The core temperature (Fig. 2) showed proportional temperature kinetics but slightly lower maximum values compared

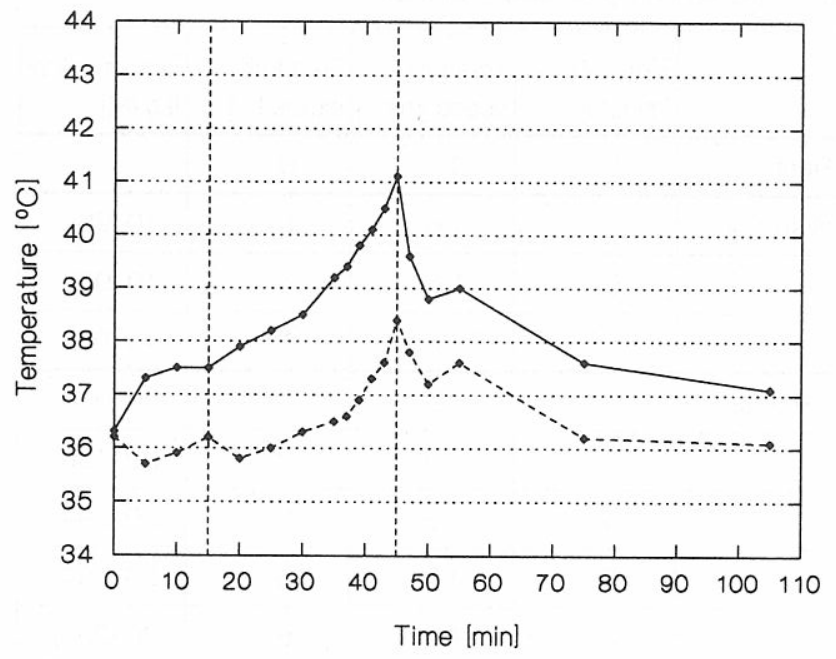

Warm Up Exercise

Recovery

\section{- Blood right cardiac ventricle -...-- Blood jugular vein}

Fig. 2: Blood temperatures changes of the horse „Quai du Manoir" during warm up, exercise and recovery.

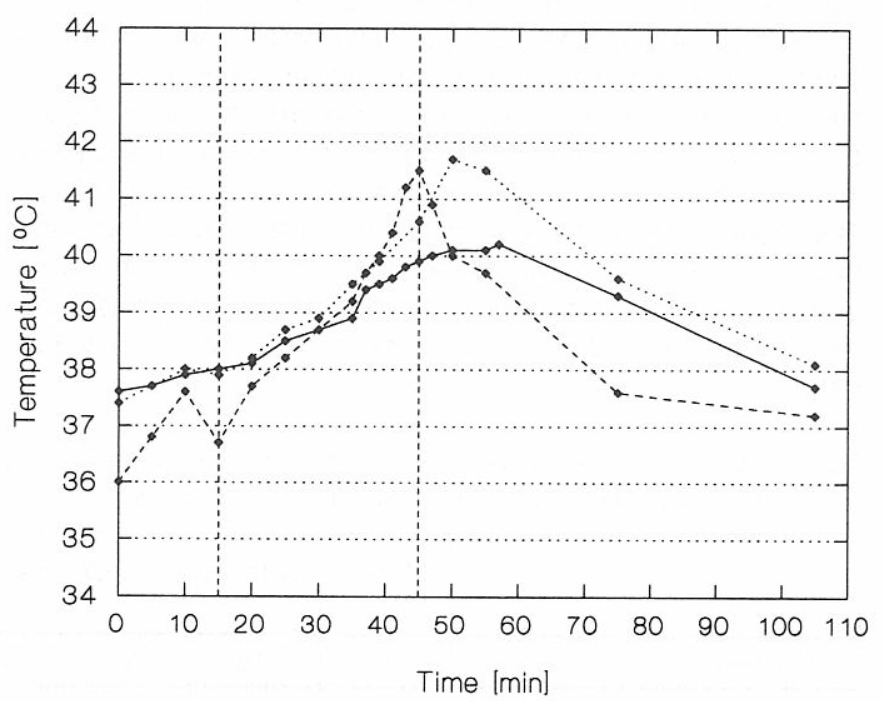

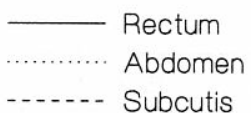

Fig. 3: Abdominal, rectal and subcutaneous tissue temperatures of the horse "Quai du Manoir" during warm up, exercise and recovery.

to temperatures measured in locomotor muscles $\left(41.1\right.$ and $40.8^{\circ} \mathrm{C}$ for the two horses respectively). The temperature difference to resting values was 4.8 respectively $4.3^{\circ} \mathrm{C}$. The smallest temperature increases $\left(2.2\right.$ resp. $\left.2.5^{\circ} \mathrm{C}\right)$ and lowest peak temperatures post exercise $\left(38.4\right.$ resp. $\left.38.5^{\circ} \mathrm{C}\right)$ were recorded in the jugular 
vein (Fig. 2). Interestingly, during the first 20 minutes of exercise, where the intervals lasted 5 minutes, a striking and consistent temperature difference of 2.0 to $2.2^{\circ} \mathrm{C}$ between blood temperature of the jugular vein and the right cardiac ventricle was observed in both horses. This difference increased during the second phase of exercise, where intervals lasted 2 minutes and was consistently 2.7 to $2.9^{\circ} \mathrm{C}$. Temperatures of the subcutaneous tissues (Fig. 3) peaked within the first 3 minutes post exercise at 41.5 and $40.4^{\circ} \mathrm{C}$ respectively. The temperature difference to resting values was 5.5 respectively $6.4^{\circ} \mathrm{C}$. In the abdominal cavity (Fig. 3) the temperature gradients rose similarly and reached comparable peak temperatures as measured at the body core (41.7 resp $40.9^{\circ} \mathrm{C}$ ) with the difference, that peak values were attained later, at 5 minutes post exercise. The rectal temperatures (Fig. 3) showed the typical delayed rise which peaked with maximal values of 40.2 respectively $39.3^{\circ} \mathrm{C}$ only $10-15$ minutes after exercise. The temperature difference to resting values was 2.6 respectively 2.3 degrees. In one horse air aspiration into the rectum at the start and end of the exercise phase provoked temperature drops of 1.5 degrees. The masseter (Fig. 1), as non-locomotor muscle was heated passively with increasing heat dissipation through blood flow. Maximal temperatures stayed at the lower range of measured peak temperatures.

One hour post exercise, the compartment temperatures - with exception of the jugular blood temperature - stayed to a variable extent $\left(0.4-3.3^{\circ} \mathrm{C}\right)$ elevated. Jugular blood temperatures equalled consistently in both horses initial resting temperatures and in one horse the rectal temperature returned to the pre exercise level.

\section{Discussion}

This study demonstrates the temperature/time distribution patterns and their kinetics in the exercising horse from the heat generating muscles through the cardiovascular system by heat conduction to the skin for heat convection and evaporation, and expounds blood flow shifts during and after exercise to and from exercise relevant organs such as locomotor muscles.

Incremental exercise test including draught work produced a substantial thermal load in the two horses tested. Local temperature changes (absolute temperatures and temperature/lag time association) observed during the present study at the highest exercise level are similar to those reported by Hodgson et al. (1993) at 65 $\%$ of $\mathrm{VO}_{2 \max }$ with mean heart rate of $170 \mathrm{bpm}$. However the above values in our study with the horses working at near maximal intensities (heart rates $>200 \mathrm{bpm}$ and plasma lactate concentrations $>\left.12 \mathrm{mmo}^{-1}\right|^{-1}$ ) were lower than the respective data by Hodgson et al. (1993) at $90 \% \mathrm{VO}_{2 \max }$ and similar heart rates. Various conditions and circumstances may influence metabolic heat generation and dissipation, such as the type of horse, the individual state of training, heat adaptation and hydration (Naylor et al., 1993), the warm up and exercise protocol as well as environmental conditions and temperature monitoring techniques. All these variables are usually not identical between different experimental protocols and comparisons of results of absolute temperature values between experiments have therefore to be interpreted with caution.

Metabolic heat load is produced proportionally to the intensity of exercise and tends to plateau near maximal exercise intensities (Hodgson et al., 1993). Interestingly during this specific incremental exercise test, temperatures of all compartments rose exponentially with time and each work load level. A linear response of the heart rate to increasing workload was expected; however in this experiment we observed an exponential increase, reflecting the nature of the exercise protocol, where we combined treadmill velocity, slope and draught load to augment work intensity.

Rectal temperatures did not adequately represent core and compartment temperatures and should not be used as the sole measuring site to assess heatload of strenuously exercising horses. This has been observed by others as well (Hodgson et al., 1993). The rectal temperature increase over time was obviously slower compared to any other body compartment. The rectal temperatures never reached maximal core temperature and peaked after exercise with a substantial lag time of 10-15 minutes, likely due to blood flow redistribution. This aspect of time lag should be carefully taken into consideration when correcting blood gas measurements to temperature (Jones et al., 1989). The rectal temperature neither reflected the thermal situation in the abdominal cavity, as abdominal temperatures peaked earlier and at $1.5^{\circ} \mathrm{C}$ higher. The lower rectal temperatures recorded may be the result of the different vascular supply (Arteria mesenterica caudalis) and/or the retroperitoneal location (insulation) of the rectum. The slow and incomplete equilibration of stored metabolic heat to the rectum after exercise, resulted in an underestimation of the body core temperature. This is an important point to consider by veterinarians monitoring heat stress in horses during equestrian events. Guidelines for endurance events indicate that rectal temperature of $>103^{\circ} \mathrm{F}\left(>39.4^{\circ} \mathrm{C}\right)$ should not be exceeded.

Muscle temperature differences of $1-1.5^{\circ} \mathrm{C}$ were consistently measured between the middle gluteal and semitendinosus muscle. These differences are not only entirely attributed to different functional activity of different locomotor muscle groups, but might also be a reflection of temperature sampling depth. In preliminary tests, where left and right corresponding muscles of the same horse were simultaneously measured and the thermocouple tips were not precisely placed at the same depth, temperature curves with same kinetics but variable offsets were recorded. Insulation may contribute to this temperature difference but also local metabolic activity within a whole muscle could explain the higher metabolic heat generation. Armstrong et al. (1992) demonstrated in their blood flow microsphere studies, that within the same anatomically defined muscle, deep muscle fiber portion showed higher structural and biochemical oxidative capacity, higher blood flow and earlier recruitment of oxidative fibres (type I and IIA) during exercise and therefore higher metabolic turnover compared to superficial portions.

Moderate elevations of muscle tissue temperature up to $40^{\circ} \mathrm{C}$ during short term exercise benefit muscular performance by accelerating muscle cell energy metabolisms (Astrand and Rohdahl, 1986) and increasing oxygen diffusion from red blood cells into tissue by shifting the oxyhaemoglobin dissociation curve to the right (Reeves, 1980). However a number of tissues, particularly the central nervous system are extremely susceptible to the noxious effects of hyperthermia $\left(>42^{\circ} \mathrm{C}\right)$. In our study the highest muscle temperature was $43.3^{\circ} \mathrm{C}$ and peak core body temperature was $41.1^{\circ} \mathrm{C}$. Even higher muscle temperatures with maximal values of $45^{\circ} \mathrm{C}$ were reported by Lindholm and Saltin (1974). Maximal body core temperature (pulmonary artery) of $42.8^{\circ} \mathrm{C}$ is reported by Hodgson et al. (1993). The same study demonstrates an insignificant lower blood temperature $\left(0.4^{\circ} \mathrm{C}\right)$ in the carotid artery draining to the brain. Compared to these observations, our study demonstrated a consistent significant temperature difference between body core and jugular vein blood, thus indicating the likely presence of an efficient cooling mechanism protecting from cerebral hyperthermia. As the horse does not have a counter-current 
heat exchange mechanism related to the Rete mirabile epidurale rostrale as in ruminants, it is speculated, that in the horse the arterial blood gets cooled down over a heat exchange mechanism related to the venous plexus of the nasal cavity before draining to the brain (Hodgson et al., 1994).

\section{References}

Astrand, P. O. and Rodahl, K. (1986): Textbook of work physiology Physiological bases of exercise. pp. 295-636. New York: McGrawHill Book Company.

Armstrong R. B., Essen-Gustavsson, B., Hoppeler, H., Jones, J. H., Kayar, S. R., Laughlin, M. H., Lindholm, A., Longworth, K. E., TayIor, C. R. and Weibel, E. R. (1992): Oxygen delivery at $\mathrm{VO}_{2 \max }$ and oxidative capacity in muscles of Standardbred horses. J Appl Physiol 73(6), 2274-2282.

Hodgson, D. R., McCutcheon, L. J., Byrd, S. K., Brown, W. S., Bayly, W. M., Brengelmann, G. L. and Gollnick, P. D. (1993): Dissipation of metabolic heat in the horse during exercise. J Appl Physiol 74(3), $1161-1170$.

Hodgson, D. R., Davies, R. E. and McConaghy, F. F. (1994): Thermoregulation in the horse in response to exercise. Br Vet $\mathrm{J} 150$, 219-235.

Jones, J. H., Taylor, C. R., Lindholm, A., Straub, R., Longworth, K. E. and Karas, R. H. (1989): Blood gas measurements during exercise: errors due to temperature corrections. J Appl Physiol 67, 879-884.

Lindholm, A. and Saltin, B. (1974): The physiological and biochemical response of Standardbred horses to exercise of varying speed and duration. Acta Vet Scand 15, 1-19.

Naylor, J. R. J., Bayly, W. M., Gollnick, P. D., Brengelmann, G. L. and Hodgson, D. R. (1993): Effects of dehydration on thermoregulatory responses of horses during low-intensity exercise. J Appl Physiol 75(2), 994-1001.

Reeves, R. B. (1980): The effect of temperature on the oxygen equilibrium curve of human blood. Respir Physiol 42, 317-328.

\section{Acknowledgements}

The expert technical assistance of Gérard Oulevey, Heinz Boschung and Kristin Jostarndt are gratefully acknowledged. This work was supported by the Swiss Federal Stud, Avenches and equipment support was provided by ABB Metrawatt, Villars-surGlâne, Switzerland. A special thank to Jörg Auer for revising the manuscript.

Michael A. Weishaupt

Department of Veterinary Surgery

University of Zurich

Winterthurerstrasse 260

$\mathrm{CH}-8057$ Zurich

Switzerland

Henry Staempfli

Veterinary Teaching Hospital

Ontario Veterinary College

University of Guelph

Guelph, Ontario

Canada N1G 2W1

Rudolph Billeter

Institute of Anatomy

University of Berne

Bühlstrasse 26

$\mathrm{CH}$-3000 Bern 9

Switzerland

Reto Straub

Clinic of Equine Medicine

University of Berne

Länggass-Strasse 124

$\mathrm{CH}$-3012 Berne

Switzerland 